\title{
UNEMPLOYMENT, LABOUR FORCE PARTICIPATION, AND URBANIZATION IN THE CARIBBEAN
}

\author{
Kempe Ronald Hope*
}

\section{Introduction}

The single most important influence on urban concentration has been the nature and location of employment. Both migrants and individuals born in the urban areas are required to find subsistence, but the speed with which they initiate this search, the intensity with which they conduct it, and the eventual outcome, differs between age groups and ethnic groups, and by level of education and other factors. ${ }^{1}$

The availability of jobs is, arguably, the most important element in the quality of urban life. Perhaps too much of the debate about the urban condition focuses on the supply of services such as piped water, transportation, housing, and education. Although provision of these services can vastly improve the well-being of the urban poor, it does not solve their basic problem, which is poverty. Productive employment does. ${ }^{2}$ This paper examines the primary issues related to unemployment and labor force participation within the context of urbanization in four Caribbean countries-Barbados, Guyana, Jamaica, and Trinidad and Tobago.

\section{The Extent of Unemployment in the Caribbean}

It is a mere tautology that the level of urban unemployment or underemployment is due to the differences between the rate of growth of the active population in urban centers and that of the employment opportunities created there. This is true for the rural areas also. However, like most of the Third World, the problem is of greater significance in the urban areas of the Caribbean because of its greater visibility in comparison with the hidden unemployment in the rural areas. But, since hidden unemployment and underemployment are not usually included in the official unemployment data, the urban unemployment rate tends to be understated, particularly during prolonged recessionary periods when the number of discouraged workers tends to increase.

In Table 1 we see the national unemployment rates for the Caribbean. In Barbados, the period from 1970 to 1980 witnessed an 18 percent increase in the labour force, due to a substantial rise in the female participation rate and to population increase. Consequently, although employment expanded over the period, the overall unemployment rate jumped from 9 percent in 1970 to 13.7 percent in 1980. In Guyana, the unemployment rate increased from roughly 16 percent in 1970 to an estimated 20 percent at present. Guyana's labour force in 1980 was 34 percent of the total population. A partial factor giving rise to Jamaica's record unemployment rates is the curtailment of imports which occurred in the 1970s and which in turn provoked acute shortages of raw materials and intermediate goods, thereby further reducing the level of economic activity in the manufacturing, construction, and distributive trade sectors. At present, the situation is further compounded by the lack of foreign exchange to import raw materials. In Trinidad and Tobago, where there is a vibrant private sector, the current unemployment rate is only 8.7 percent.

*Fulbright Professor of Economics and Public Policy, University of the West Indies, Kingston, Jamaica. 


\section{TABLE 1}

National Unemployment Rates in the Caribbean, 1960-80

(Percent)

\begin{tabular}{lrrc}
\hline COUNTRY & 1960 & 1970 & 1980 \\
\hline BARBADOS & 8.0 & 9.0 & 13.7 \\
GUYANA & 8.0 & 16.0 & $20.0^{\mathrm{a}}$ \\
JAMAICA & 13.0 & 18.0 & 27.3 \\
TRINIDAD AND TOBAGO & 12.0 & 12.5 & 8.7 \\
\hline
\end{tabular}

SOURCES: World Bank, World Tables 1976 (Baltimore: Johns Hopkins University Press, 1976), pp. 514-517; Inter-American Development Bank, Economic and Social Progress in Latin America (Washington, D.C.: IDB, Several Years); and Caribbean Development Bank, Annual Report 1982 (St. Michael, Barbados: CDB, 1983), p. 24.

amost recent estimate.

In Table 2 we see the limited data on urban and rural unemployment rates that is currently available. Information on urban unemployment in the Caribbean is difficult to obtain. Such data tend not to be developed in the country censuses. Moreover, when such data are developed, their accuracy is highly questionable due to the qualitative differences in the census questionnaires and differences in the definitions of urban areas. However, despite those limitations it is clear from the limited data and from observation that urban unemployment rates exceed by far the rural unemployment rates. In Jamaica the ratio of urban to rural unemployment rates is 1.5 while for Trinidad and Tobago it is 1.9.

Unemployment is at too high a level in most Caribbean nations and is increasing rapidly, perhaps with the exception of Trinidad and Tobago where there still exists a vibrant private sector and where economic growth rates, though not spectacular, have been steady. Much of the increase is in the urban centers, where high rates of open unemployment are added to the more typical underemployment in both the urban and rural areas. The conversion of rural underemployment into open unemployment in urban centers changes both the magnitude and the political nature of the problem.

In general, rapid rural-urban migration of unskilled labour is more significant in explaining the magnitude of the urban unemployment. In urban areas there is actually a shortage of high-level professionals. This is the case because of the considerable emigration of high-level personnel from the Caribbean. The incidence of emigration among high-level manpower from Trinidad and Tobago is currently averaging 15 percent. Annual emigration of professional, technical, and management personnel from Jamaica represents roughly 10 percent of the incremental growth of manpower in that nation. In Guyana, the magitude of emigration is much greater. There, high-level personnel constitute about 25 percent of the permanent emigrants per year. In Barbados, similar patterns prevail ${ }^{3}$.

\section{TABLE 2}

Urban and Rural Unemployment Rates in the Caribbean (Percent)

\begin{tabular}{lccc}
\hline & & \multicolumn{2}{c}{ UNEMPLOYMENT RATE } \\
\cline { 3 - 4 } COUNTRY & YEAR & URBAN & RURAL \\
\hline GUYANA & 1965 & $20.5^{\mathrm{a}}$ & - \\
JAMAICA & 1960 & $19.0^{\mathrm{a}}$ & $12.4^{\mathrm{b}}$ \\
TRINIDAD AND TOBAGO & 1971 & 16.5 & $8.7^{-}$ \\
\hline
\end{tabular}

SOURCES: David Turnham and I. Jaeger, The Employment Problem in Less Developed Countries: A Review of Evidence (Paris: OECD, 1971), pp. 57; 134-135; and Lyn Squire, Employment Policy in Developing Countries: A Survey of Issues and Evidence (New York: Oxford University Press, 1981), p. 68.

acapital city only.

bexcluding capital city. 
Industrial job creation is not increasing at a rate that is high enough to absorb migration from rural areas, however. In some of the countries, such as Guyana, the rate of industrial job-creation has even been negative. However, at the base of the problem lies the too-rapid growth of the urban labour force.

Unquestionably then, rapid urbanization is the primary factor influencing urban unemployment in the Caribbean. Given the rates of internal migration and the natural population increase in the urban areas, it is not surprising that urban unemployment has emerged as a serious problem in the Caribbean. When unemployment and underemployment in the Caribbean persists it means a loss of productive activity for the economy as a whole, but to the unemployed it means a loss of income, less food, poor shelter, less of all the basic elements needed to satisfy human needs, and a general perpetuation of their state of poverty. ${ }^{4}$ This hopeless economic situation in turn can result and has resulted in unmanageable social problems such as high crime rates in Jamaica and Guyana, ${ }^{5}$ for example.

In all of the Caribbean nations, the rate of unemployment is higher than in the United States and other industrial countries at any time in this century including the depression. Thus, the problem of unemployment is on the one hand in a sterile statistic used by economists, but on the other hand, to millions of Caribbean citizens it signifies frustration, idleness, and poverty. ${ }^{6}$ Within that context the growth, composition, and pattern of labour force participation becomes significant.

\section{Age and Sex Composition and Unemployment}

One of the main characteristics of urban unemployment in the Third World is that the proportion of the young people who are affected is generally large. In nearly every case, including the Caribbean, the unemployment rates in the 15-24 age group are disproportionately high. The most recent data estimate that the rate for that age group in Guyana is 40 percent while in Trinidad and Tobago it is 26 percent. Similarly, females have lower work rates and higher rates of unemployment. Barbados shows appreciably higher work rates than the other countries while for the primary work force groups of males ages 25 to 29 years, Jamaica and Trinidad and Tobago show unusually low work rates. ${ }^{7}$

The general problem of manpower utilization in the Caribbean, as measured by work rate data, is highly concentrated among females and the younger members of the working age population. Approximately 80 percent of the non-working potential labour force did not want a job, the vast majority being females engaged in housekeeping. ${ }^{8}$ This suggests that the actual socioeconomic costs of the unemployment problem tend to be far more serious in the case of younger males. Those who said that they wanted work tended to be highly concentrated among those seeking first jobs. The youngest age group (14 to 19 years old) accounted for approximately half of all work seekers in the Caribbean region. There were roughly twice as many males as females in both the 14 to 19 , and the 19 and over age groups. ${ }^{9}$ The region is therefore faced with a continuing problem of providing employment for young workers, to absorb young school leavers into the economic life of the countries.

\section{Educational Levels and Unemployment}

Although data on educational levels are not abundant, they are sufficient for valid conclusions to be drawn from them. Unemployment is much more of a problem for those individuals having moderate educational qualifications. The most recent available data for Trinidad and Tobago, for example, suggest that the unemployment rate was about 10 percent of the labour force for those with less than 5 years of education, and about 6 percent for those with a completed secondary school education or higher. ${ }^{10}$

Education in the Caribbean is a much sought after commodity and its pursuit a very competitive activity. In many of the countries, such as Guyana, education is encouraged and provided universally through to the university degree. In such an environment, then, academic achievement tends to set individuals apart, particularly as it relates to the hiring process since it becomes a primary factor in the process of staff determination. In the urban areas of the Caribbean the significance of education to the employment situation is entrenched because acquisition of education and practice of skills usually require residency in the urban areas.

\section{Size, Growth, and Sex Composition of the Labour Force}

As seen in Table 3, during the period 1960-2000 the labour force in the Caribbean is expected to grow two-fold in absolute terms. At present, the labour force in the Caribbean is estimated at about 30 percent 
of the total population. The number of workers in the labour force is dependent on both the pool of existing workers and those entering the labour force. The growth rate depends upon population increase, net migration, and labour force participation. The two primary socio-economic factors influencing labour force participation are education and socialization. In terms of education, there is a strong correlation between increased education and increased labour force participation for both men and women. Socialization influences an individual's perception of his or her role in society and this affects the decision on whether to enter the labour force. As economies expand, for example, there is a decrease in the labour force participation of children since parents feel education is a much more important alternative; on the other hand, there is an increase in the participation of women since they seek financial benefits instead of staying at home. These two factors are interrelated. For example, since more and more Caribbean women are seeking higher education and entering the labour force not only could their fertility rate tend to decline in the future but also the population growth rate could fall.

In examining the growth rates of the total labour force in each of the four nations as well as its male and female components, as shown in Table 4, several conclusions can be drawn, all of which have implications for urban unemployment. First, in the decade and half preceding 1970, the growth of the total labour force in each country was modest and, with the exception of Guyana, all of the countries had periods of negative growth. Second, with the exception of Jamaica, the rate of growth of the female sex in the labour force was greater than that of the male sex after 1970. This reflects a trend which is becoming more pronounced, namely, the increase of women in the labour force. Even though their total number has remained relatively small in comparison to men, the increase has been enough to influence the average growth of the labour force as a whole.

\section{Sectoral Composition of the Labour Force}

The sectoral distribution of the labour force is shown in Table 5. As can be seen, the patterns of change of sectoral activity of the labour force between 1960 and 1980 has been quite similar. During the past twenty years important shifts have occurred in the sectors in which work is sought. Whereas in 1960, a large number in agriculture, by 1980 the majority of workers were employed in industry and services with the services sector having the highest proportion. It is clear therefore that the shift taking place in the labour force is away from agriculture and into services as the primary sector in the Caribbean. While the proportion involved in agriculture in the Caribbean continues to be considerably higher than in the more developed countries of the world, the numbers in the services sector are rapidly approaching those of the more developed countries. The major difference has been that only about one-third of the workers in the Caribbean are in industry whereas in the developed nations it is almost twice that percentage. However, when comparing the Caribbean to Africa and Asia it was found that in the latter two regions agricultural activities have tended to dominate the sectoral composition of the labour force by a wide margin.

The growth in labour force activity in the services sector has been accompained by another trend in

\section{TABLE 3}

Caribbean Labour Force, 1960-2000

(Thousands)

\begin{tabular}{lrrrrrrrrr}
\hline COUNTRY & 1960 & 1965 & 1970 & 1975 & 1980 & 1985 & 1990 & 1995 & 2000 \\
\hline BARBADOS & 91 & 89 & 90 & 98 & 107 & 115 & 125 & 133 & 143 \\
GUYANA & 173 & 187 & 204 & 242 & 288 & 341 & 391 & 442 & 493 \\
JAMAICA & 608 & 630 & 636 & 672 & 749 & 858 & 966 & 1071 & 1171 \\
TRINIDAD \& & & & & & & & & & \\
$\quad$ TOBAGO & 281 & 285 & 314 & 354 & 403 & 453 & 495 & 533 & 568 \\
TOTAL & 1153 & 1191 & 1244 & 1366 & 1547 & 1767 & 1977 & 2179 & 2375 \\
\hline
\end{tabular}




\section{TABLE 4}

Average Annual Rates of Growth of Caribbean Labour Force by Sex, 1955-2000 (Percentages)

\begin{tabular}{|c|c|c|c|c|c|c|c|c|c|c|c|c|}
\hline \multirow{2}{*}{ Period } & \multicolumn{3}{|c|}{ Barbados } & \multicolumn{3}{|c|}{ Guyana } & \multicolumn{3}{|c|}{ Jamaica } & \multicolumn{3}{|c|}{ Trinidad \& Tobago } \\
\hline & Total & Male & Female & Total & Male & Female & Total & Male & Female & Total & Male & Female \\
\hline $1955-60$ & -1.30 & -1.29 & -1.30 & 1.09 & 1.39 & 0.13 & -1.05 & -1.45 & -0.35 & 2.33 & 2.12 & 2.93 \\
\hline $1960-65$ & -0.55 & -0.18 & -1.06 & 1.57 & 1.40 & 2.13 & 0.72 & 0.44 & 1.19 & 0.34 & -0.59 & 2.72 \\
\hline $1965-70$ & 0.31 & 0.65 & -0.20 & 1.73 & 1.61 & 2.12 & 0.18 & -0.10 & 0.64 & 1.92 & 2.07 & 1.58 \\
\hline $1970-75$ & 1.67 & 1.63 & 1.74 & 3.48 & 3.29 & 4.08 & 1.10 & 1.27 & 0.83 & 2.41 & 2.28 & 2.72 \\
\hline $1975-80$ & 1.81 & 1.80 & 1.81 & 3.50 & 3.29 & 4.12 & 2.21 & 2.31 & 2.05 & 2.63 & 2.45 & 3.04 \\
\hline $1980-85$ & 1.44 & 1.51 & 1.33 & 3.45 & 3.24 & 4.06 & 2.75 & 2.67 & 2.88 & 2.37 & 2.18 & 2.78 \\
\hline $1985-90$ & 1.58 & 1.57 & 1.59 & 2.91 & 2.72 & 3.47 & 2.48 & 2.45 & 2.53 & 1.87 & 1.68 & 2.29 \\
\hline $1990-95$ & 1.41 & 1.39 & 1.44 & 2.68 & 2.52 & 3.10 & 2.27 & 2.18 & 2.43 & 1.60 & 1.41 & 2.00 \\
\hline $1995-2000$ & 1.43 & 1.32 & 1.60 & 2.48 & 2.27 & 3.03 & 2.07 & 1.94 & 2.27 & 1.38 & 1.16 & 1.81 \\
\hline
\end{tabular}

SOURCE: Same as for Table 3.

the evolution of the economies of the Caribbean. The growth of services sector employment has occurred together with the urban population explosion and the growth of women in the labour force. The services sector is the main sector absorbing women in the labour force. This may be happening at a quicker pace than the growth in the women's labour force because the services sector has grown at the expense of agriculture and industry since the late 1950s. Though the rapid growth of services sector activity is a new phenomenon in the Caribbean economy, it can be stated that one of the reasons the supply of labour has shifted from agriculture to the services and industry sectors has been the greater opportunities for employment in that modern sector which is located exclusively in the urban areas. The declining share of agriculture in total employment is a reasonable quantitative index of the degree and evolution of urbanization.

It is obvious then that the structural changes occurring in the sectoral composition of the Caribbean labour force are a major contributor to the rapid urbanization occurring in the Caribbean. The services sector (of which the major employer is the government) and the industry sector are found in the urban centers. They are usually in one major city which is always, in the case of the Caribbean, the capital

TABLE 5

Sectorial Composition of Caribbean Labour Force, 1960, 1970, 1980

(Percentages)

\begin{tabular}{|c|c|c|c|c|c|c|c|c|c|c|c|c|}
\hline \multirow[t]{2}{*}{ Sector } & \multicolumn{3}{|c|}{ Barbados } & \multicolumn{3}{|c|}{ Guyana } & \multicolumn{3}{|c|}{ Jamaica } & \multicolumn{3}{|c|}{$\begin{array}{l}\text { Trinidad } \\
\text { \& Tobago }\end{array}$} \\
\hline & 1960 & 1970 & 1980 & 1960 & 1970 & 1980 & 1960 & 1970 & 1980 & 1960 & 1970 & 1980 \\
\hline $\begin{array}{l}\text { Agricul- } \\
\text { ture }\end{array}$ & 26 & 20 & 9 & 34 & 28 & $31^{\mathrm{a}}$ & 39 & 29 & 21 & 22 & 19 & 16 \\
\hline Industry & 27 & 32 & $26^{a}$ & 29 & 33 & $33^{a}$ & 25 & 26 & 25 & 34 & 35 & 36 \\
\hline Services & 47 & 48 & $65^{a}$ & 37 & 39 & $36^{a}$ & 36 & 45 & 54 & 44 & 46 & 48 \\
\hline
\end{tabular}

SOURCES: World Bank, World Tables 1980 (Baltimore: Johns Hopkins University Press, 1980), pp. 462-463; World Bank, World Development Report 1982 (New York: Oxford University Press, 1982), pp. 146-147; and InterAmerican Development Bank, Economic and Social Progress in Latin America (Washington, D.C.: IDB, Several Years).

amost recent estimate. 
city. This type of urban primacy is mirrored in the urban-size distribution by the way one city dominates all others. ${ }^{11}$ For example, Kingston, Jamaica, has twelve times the population of Montego Bay.

Such urban primacy has permitted the creation of organized labour markets which require certain minimum size markets. The organized labour markets comprise virtually all public sector jobs and that part of the private sector in which conditions of employment are subject to some degree of collective bargaining. They account for between thirty and fifty percent of total employment, and wages and related benefits tend to be somewhat better than in the unorganized labour market. ${ }^{12}$

However, how effectively and efficiently the service and industry sectors can continue to absorb the influx of workers remains to be seen. This, of course, will be dependent on the extent to which the traditional agricultural sector is left behind the more modern industrial and service sectors. Since the modern sector is often characterized by relatively higher wage rates, there is usually a supply of labour available to this sector. Therefore, the growth of employment in the modern sector is primarily determined by the growth in the demand for labour. ${ }^{13}$

\section{Participation Rates of the Labour Force}

In Table 6 the participation rates of the Caribbean labour force are exhibited for 1970 and 1975. The trends in participation rates were not substantially different from what was obtained in other regions. The major difference is that, until recently, the number of women entering the labour force of the Caribbean countries was small. Currently, the female labour force participation rate in the Caribbean region is approximately 19.5 percent and is lower than that obtained in most of Asia, Western Africa, and Eastern Africa.

Where country differences in participation rates exist, they are only partially due to differences in the age and sex composition of the populations. The differences narrow down in the case of males when the rates are standardized for differences in age distribution, but actually increase in the case of females. Thus, the relatively low female participation rate in Guyana can be explained by the age composition of the population. About 55 percent of Guyana's population is below the age of twenty. However, the relatively high female participation rates of Barbados cannot be attributed to the island's particular age structure.

In general, participation rates tend to be significantly lower among the younger age groups of the working population than those of older workers. Similarly, females typically have lower participation rates than males of corresponding age. Differences in age- and sex-specific participation rates in the Caribbean region conform to this general pattern, but the relative magnitudes of the differences appear to be atypically large. ${ }^{14}$ Perhaps the most visible change occurring with respect to labour force participation rates in the Caribbean, and hence influencing economic life, is the rapid entrance of women into the work force. As Table 4 shows, the female labour force in the four countries will continue to outgrow the male labour force into the year 2000 and there is no reason to believe that this expansionary trend will not continue past the turn of the century. The number of women working or seeking jobs in the four countries as a whole will grow at an annual rate of 2.5 percent between 1975 and the end of the century while the rate for men will be 2 percent.

Another significant aspect of this phenomenon is that while the labour force participation rate for women as a whole, is rising, importantly, that of the younger age group is increasing faster and, even more importantly, so is the proportion of women living and working in urban areas. For all the countries, women outnumber men in urban areas as shown above. Recent partial analyses suggest that female urban labour force growth is even higher than had been projected. However, a more precise judgment will require the evidence which will be available after all the countries complete the computation of the data from the 1980 censuses and when various international organizations such as the United Nations and the International Labour Office have had an opportunity to recalculate the forecasts. This whole process usually takes four to seven years after the census is completed.

This urban orientation of the female population of the Caribbean can be further gleaned from data on the sectoral distribution of the female labour force as discussed in the previous section. Caribbean women working in non-agricultural activities by far outnumber working women in the agricultural sector. In Jamaica, for example, 82 percent of the women in the labour force have jobs or are seeking jobs in the non-agricultural sector. Working women in the Caribbean were twice as likely to hold a 


\section{TABLE 6}

Caribbean Labour Force Participation Rates by Sex, 1970 and 1975

(Percentage)

\begin{tabular}{lccc|ccc}
\hline Country/ & \multicolumn{3}{c|}{1970} & \multicolumn{3}{c}{1975} \\
\cline { 2 - 7 } Region & Total & Men & Women & Total & Men & Women \\
\hline Barbados & 40.5 & 48.7 & 32.4 & 40.0 & 50.3 & 30.6 \\
Guyana & 30.1 & 46.5 & 13.7 & 30.6 & 46.3 & 15.0 \\
Jamaica & 32.2 & 42.1 & 22.7 & 33.1 & 41.2 & 25.2 \\
Trinidad \& & & & & & & \\
Tobago & 33.1 & 48.1 & 18.5 & 35.1 & 49.0 & 21.2 \\
Caribbean & 33.5 & 46.0 & 21.3 & 35.3 & 50.4 & 19.5 \\
\hline
\end{tabular}

SOURCES: Same as for Table 3; and Norma Abdulah, The Labour Force in the Commonwealth Caribbean: A Statistical Analysis (St. Augustine, Trinidad: Institute of Social and Economic Research, University of the West Indies, 1977 ), p. 13.

white-collar job as men. For the four countries as a whole, 27.6 percent of the working women had whitecollar jobs compared to 12.8 percent of working men. However, there are some striking differences within each country. For example, 36.8 percent of working women in Trinidad and Tobago had a white-collar job, compared with only 23.4 percent of working women in Jamaica. ${ }^{15}$ Clearly, opportunities exist for women to obtain good jobs. They are provided with the same opportunity as men to prepare themselves and acquire the necessary skills and training and there is a strong correlation between women's increased educational opportunities and higher female labour force participation rates.

Another very important aspect in the issue of female labour force participation is the increasing number of female-headed households, which is a growing phenomenon in the Caribbean. In the Commonwealth Caribbean, 35 percent of all heads of households are women. ${ }^{16}$ For women who are heads of households, the most viable way of securing an income, and hence safeguarding their families, is to enter the labour force.

The above discussion on labour force participation, therefore, points to the changing economic and social dynamics of the roles of women in the Caribbean particulariy as it influences the process of rapid urbanization. This will have a profound effect on regional economic development in the future, especially since the consequences, of these changes have yet to be incorporated into the institutional, social, and economic structures in the Caribbean.

\section{Policy Implications and Conclusions}

As far back as 1933 Allan Fisher espoused a stage theory of development that touted the rising significance of the services sector as economic development proceeds. ${ }^{17}$ A little more than two decades later Colin Clark elaborated essentially the same idea on the dynamics of labour force composition by arguing that as time goes on and economic development occurs, the number of workers in the agricultural sector tends to decline relative to the numbers in manufacturing, which in turn decline relative to the numbers employed in the services sector. ${ }^{18}$ These two frameworks became known in the literature as the "Clark-Fisher hypothesis" and remain valid even more so today than before.

In the Caribbean, the same pattern has been observed. As the agricultural sector declined with the passing of time and the movement toward modernization took hold, all of the nonagricultural occupational groups became more highly urbanized. In the case of industry and services, this tendency reinforced a pre-existing urban dominance in the primate capital city. As a result, after the labour force growth began to exceed the rate of urban job expansion, urban employment became a major dilemma.

Perhaps the primary concern with the urban employment problem in the Caribbean is that it includes a pool of persons who, because they are not employed, are not contributing to their own well-being and the gross national output. ${ }^{19}$ This is a problem not only for the unemployed individual but, in addition, it also influences unsuccessful jobseekers to abandon their search, thus creating a cadre of discouraged 
job-seekers, further reducing national productivity. Moreover, the concentrated incidence of unemployment on such a politically vocal and influential group makes this an especially pressing social issue in the Caribbean.

When persistent unemployment causes individuals to drop out of the labour force they cease to be counted as unemployed. Thus, as useful as the unemployment rate may be, it does not represent a full picture of the labour market. Low participation rates may be an indication of the presence of discouraged workers, and a signal that labour market conditions may well be worse than the rate of unemployment indicates. In the Caribbean, participation rates by age, sex, and ethnicity provide an insight into labour market conditions that the unemployment rate alone does not give. These insights can be very useful in the planning of remedial action.

Caribbean policy-makers seem to have regarded rapid urbanization as an irresistible force of nature and have done very little to manage it. Policies to guarantee a steady growth of jobs are almost nonexistent. However, the reduction of urban unemployment must be given priority in the development plans of the Caribbean nations. A reduction of urban unemployment can be made through a slowing down of the process of urban population growth. This, in turn, implies a slowing down of rural-urban migration.

A solution to the urban employment problem would be difficult enough if it were just a matter of jobs. However, the kinds of jobs, and their contributions to increases in output, are also important if the labour force is to be productive.

Increasing the number of jobs now would, of course, help raise income but the problem will reoccur unless there is a continued effort to expand employment opportunities in order to match the steady growth of the labour force. The growth of output which is necessary to absorb such large numbers of workers may not be attainable for some countries. However, by not even trying to expand employment opportunities, the Caribbean governments may foredoom millions more to poverty.

\section{FOOTNOTES}

${ }^{1}$ Stuart W. Sinclair, Urbanization and Labour Markets in Developing Countries (New York: St. Martin's Press, 1978 ), p. 69. ${ }^{2}$ Kathleen Newland, City Limits: Emerging Constraints on Urban Growth (Washington, D.C.: Worldwatch Institute, 1980), p. 20.

${ }^{3}$ See Kempe Ronald Hope, "The Emigration of High-Level Manpower from Developing to Developed Countries with Reference to Trinidad and Tobago, International Migration 14, No. 3 (1976), pp. 209-218; James Sackev, "The Migration of High-Level Personnel from Guyana: Toward an Alternative Analysis," Transition 1, No. 1 (1978), pp. 45-58; and G. Ebanks, P.M. George and C.E. Nobbe, "Emigration From Barbados, 1951-1970," Social and Economic Studies 28 (June 1979), pp. 431-449.

${ }_{4}^{4}$ See Kempe Ronald Hope, "The Unemployment Problem in the Caribbean," Labour and Society 8 (July-September 1983).

5See Howard Jones, Crime, Race and Culture: A Study in a Developing Country (New York: John Wiley and Sons, 1981), pp. 150-156; and Klaus de Albuquerque and Others, Uncontrolled Urbanization in the Developing World: A Jamaican Case Study," Journal of Developing Areas 14 (April 1980), p. 365.

6Kempe Roland Hope, "The Employment Problem, Rural-Urban Migration and Urbanization in the Caribbean," Population Review 26, Nos. 1 and 2 (1982), p. 42.

${ }^{7}$ Sidney E. Chernick and Others, The Commonwealth Caribbean: The Integration Experience (Baltimore: Johns Hopkins University Press, 1978), p. 74.

8Jack Harewood, Unemployment and Related Problems in the Commonwealth Caribbean (St. Augustine, Trinidad: Institute of Social and Economic Research, University of the West Indies, 1978), p. 28.

9Sidney E. Chernick and Others, The Commonwealth Caribbean: The Integration Experience, p. 75. For a slightly varied interpretation of the data see Norma Abdulah, The Labour Force in the Commonwealth Caribbean: A Statistical Analysis (St. Augustine: Institute of Social and Economic Research, University of the West Indies, 1977), pp. 59-63.

10Jack Harewood, Unemployment and Related Problems in the Commonwealth Caribbean, p. 29.

${ }^{11}$ Alan Gilbert and Josef Gugler, Cities, Poverty, and Development (New York: Oxford University Press, 1982), p. 30.

${ }^{12}$ Sidney E. Chernick and Others, The Commonwealth Caribbean: The Integration Experience, pp. 81-82.

${ }^{13}$ A.S. Oberai, Changes in the Structure of Employment With Economic Development (Geneva: International Labour Office, 1978), p. 20.

14Ibid., p. 74.

15 Ibid., p. 76.

${ }^{16}$ See Mayra Buvinic, Women Workers in Latin America: A Structural Analysis (Washington, D.C: International Center for Research on Women, May 1981).

${ }^{17}$ Allan G.B. Fisher, "Capital and the Growth of Knowledge," Economic Journal (1933), pp. 374-389.

${ }^{18}$ Colin Clark, The Conditions of Economic Progress (London: MacMillan and Company, 1957), p. 492.

${ }^{19} \mathrm{Jack}$ Harewood, Unemployment and Related Problems in the Commonwealth Caribbean, pp. 56-57. 